\title{
On the Problems and Measures of Translation Teaching for English Majors in China
}

\author{
Jun QIN \\ Science and Technology College of Hubei University for Nationalities \\ Enshi, China \\ qinjunfanyi@126.com
}

\begin{abstract}
Translation acts as a key course among the courses of English major and plays an important role in sharpening the students' comprehensive ability to use languages in institutions of higher learning. However, in recent years, a majority of students have made it known that they achieved no good results in translation course, in which more or less problems exist. In order to find out the problems of translation teaching, this paper had a sample survey on 250 third-year students of English majors in West China universities about their response to translation teaching. With the analysis of the questionnaire, three problems have been found, and the paper finally gave some countermeasures and suggestions in the hope of attaining the goal of high quality translation teaching. To keep pace with the times, the paper also held the idea that Internet Aided Translation should be concluded in translation teaching and it also gave new ways of doing translation with the help of the Internet.
\end{abstract} majors

Keywords-problems; measures; translation teaching; English

\section{INTRODUCTION}

With the deepening of foreign exchanges, China is having an increasing demand for translation talents in communications of all professions. In the past decades, nearly all the colleges and universities in China have offered translation courses for English majors, making translation curriculum the core curriculum for them. Translation course has played a great role in cultivating students' comprehensive ability of using language. But the current translation market shows that the translation proficiency of English majors is still inadequate, which is closely related to the translation teaching. "Translation courses in some universities are neglected, and students get angry when they talk about translation courses, complaining nothing is gained in the course, and saying they get more by self-learning.[1]"

This paper tries to find out the problems in translation teaching by questionnaire survey in the hope of offering measures of translation teaching and improving the students' ability in translation practice.

\section{INVESTIGATION AND RESULTS ANALYSIS}

In order to further make clear students' attitudes towards translation courses, and the relationship between their translation proficiency and translation curriculum, the author had a sample survey on 250 third-year students of English

It is sponsored by Science and Technology College of Hubei University for Nationalities (Project No. KYJY201623). majors in West China universities. The questionnaire was given via Internet and each student who answers the questions had been paid 5 Yuan as a reward to keep the survey effective. The questions given in the questionnaire are as follows:

(1) What have you learned in the translation course?

(2) Do you apply translation theories into translation practice in the translation class?

(3) Are you satisfied with the teacher's teaching method?

(4) Do you think your translation proficiency is the result of personal efforts or the role of translation courses?

Through the questionnaire analysis, it can be seen that some problems do exist in the translation teaching for English major in colleges and universities. The following table shows the results of the survey.

TABLE I. WHAT HAVE YOU LEARNED IN THE TRANSLATION COURSE?

\begin{tabular}{|c|c|c|c|c|c|}
\hline \multicolumn{2}{|c|}{ Translation Theory } & \multicolumn{2}{|c|}{ Grammar, Words } & \multicolumn{2}{c|}{ None or Other } \\
\hline students & percent & students & percent & students & percent \\
\hline 21 & $8.4 \%$ & 106 & $42.4 \%$ & 123 & $49.2 \%$ \\
\hline
\end{tabular}

TABLE II. DO YOU APPLY TRANSLATION THEORIES INTO TRANSLATION PRACTICE IN THE TRANSLATION CLASS?

\begin{tabular}{|c|c|c|c|c|c|}
\hline \multicolumn{2}{|c|}{ Yes } & \multicolumn{2}{c|}{ No } & \multicolumn{2}{c|}{ I don't know } \\
\hline students & percent & students & percent & students & percent \\
\hline 34 & $13.6 \%$ & 163 & $65.2 \%$ & 53 & $21.2 \%$ \\
\hline
\end{tabular}

TABLE III. ARE YOU SATISFIED WITH THE TEACHER'S TEACHING METHOD?

\begin{tabular}{|c|c|c|c|c|c|}
\hline \multicolumn{2}{|c|}{ Yes } & \multicolumn{2}{c|}{ No } & \multicolumn{2}{c|}{ I don't know } \\
\hline students & percent & students & percent & students & percent \\
\hline 46 & $18.4 \%$ & 152 & $60.8 \%$ & 52 & $20.8 \%$ \\
\hline
\end{tabular}

TABLE IV. DO YOU THINK YOUR TRANSLATION PROFICIENCY IS THE RESULT OF PERSONAL EFFORTS OR THE ROLE OF TRANSLATION COURSES?

\begin{tabular}{|c|c|c|c|c|c|}
\hline \multicolumn{2}{|c|}{ Translation Course } & \multicolumn{2}{|c|}{ Person Efforts } & \multicolumn{2}{c|}{ Other } \\
\hline students & percent & students & percent & students & percent \\
\hline 37 & $14.8 \%$ & 184 & $73.6 \%$ & 29 & $11.6 \%$ \\
\hline
\end{tabular}


As can be seen from the table, $42.4 \%$ of the students believe that they learn grammar and new words in translation course. Only $8.4 \%$ of the students learn translation theory. The former is five times higher than the latter. At the same time, $65.2 \%$ of the students believe that translation theory is not applied in practice; $60.8 \%$ of the students are not satisfied with the teacher's teaching; $73.6 \%$ of the students hold that the translation achievements are the result of their own efforts. It can be concluded that the survey results show that the translation teaching in China does not make good achievement and it still needs to be improved in many aspects. To sum up, there are at least three main problems to be resolved:

(1) Translation theory and translation skills should further be used in translation teaching;

(2) The purpose of translation teaching needs to be made clearer;

(3) Teaching methods and teaching efficiency in translation need to be improved.

\section{CAUSE ANALYSIS}

With the survey and result analysis, it is found that some of the problems in the translation teaching for English majors are as follows:

(1) Students do not have clear objectives in translation studies. They do not understand the difference between translation course and intensive reading course, and believe that what they have to do in translation course is to learn grammar and vocabulary expression. They mistakenly hold the idea that the translation course is an extension of intensive reading course.

(2) The teachers do not have clear teaching objectives. For quite a long time, some translation teachers think that translation is only actual training, that is, translation exercises in all the translation class. However, translation skills and the comparative study of English and Chinese language help the students a lot and play a good role in improving their translation ability.

(3) The teaching method is not appropriate. Translation is an interesting as well as boring course that depends on how the teachers teach in class. As interest is the best teacher, teachers should first cultivate the students' interest in translation. With interest, students will be eager to have the power to learn translation well. Meantime, the students are more concerned about the process of the referenced translation, in other words, how does the translation come. So the translation process should be paid more attention to and made clear through translation practice and training.

\section{MEAsuRES AND SUGGESTIONS}

Since the problems and causes of translation teaching have been found, it is necessary to explore ways to overcome these problems. This paper tries to put forward the following suggestions for translation teaching for English majors.

\section{A. To have clear objectives of teaching.}

Whether from the nature of translation, or from the behavior of translation, it can be said that, "translation itself is a complex communication behavior, and the process of translation is a process of improving the learners' communication skills. [2]" Therefore, communication skills should taught in translation course. And it should be made clear to students that the purpose of translation is the purpose of communication. The readability and acceptance of their translation are the premise in translation process and should be paid significance to.

\section{B. To apply translation theory in practice.}

Translation course consists of both theories and practice. In translation teaching, the teachers cannot give students a piece of gold, but they can give students a "gold test pen". Professor Liu Jichun said that "translation teaching is like teaching a man to fish and if he learns how to fish, you feed him for a lifetime. [3]" If the teacher only asks his students to do translation exercises in translation course, and then gives them a referenced translation instead of teaching them translation theory and skills, the students only get to know how the article is translated and fail to know why it is translated in this way. They will be at a loss about how to translate if they encounter another translation work. The translation researcher Eugene Nida said, "translation practice without an adequate theory produces only haphazard results. [4]" Therefore, it can be also said that "translation class without an adequate theory produces only haphazard results".

\section{To focus on text and passage translation.}

Articles exist in the form of text, and language only has meaning in a context. Translation teaching should focus on texts and passages and involve students to do translation with a context idea in mind and to know well the style of a passage. Translation of message is not good as translation of flavor. But translation of flavor is not an easy doing. The best way to do is to clearly grasp the style of the original text, and then to re-create in the process of translation, and try all to keep the original flavor in the target text.

\section{To change from "teacher-centered" to "students-centered".}

Translation is a practical course, and students' participation in classroom tells the effect of translation course. So teachers should strive to develop the students subjective initiative, cultivate students' interest in translation, and help them develop a habit of translation consciousness. When doing translation, "students are like craftsmen, who personally make their own products, i.e. translation. [5]" Therefore, a "student-centered" class is a must for translation teaching.

\section{E. To have more test models rather than "closed-book test".}

With the survey in China, it is found that "closed-book test" is the only test form in most of the colleges and universities in China. However, the "closed-book test" has many drawbacks in evaluating the students translation proficiency. First, it is difficult for students to work out excellent translations in limited time. A good translation takes a long time for the translator to polish. Second, translation is a miscellaneous job, and the translators need to master a wide range of comprehensive knowledge. But it is unrealistic for most students to be versatile. So the students need to consult different data or reference books in order to thoroughly understand the original text. To solve this problem, both "open-book test" and "closed-book test" should be adopted in translation testing to give students enough time to exert their 
potential to work out excellent translation and to effectively assess the students' translation proficiency.

\section{TECHNOLOGY OF INTERNET Aided Translation}

Now people are living in an e-era in which electronic technology changed people's way of living and helped them to make human work more convenient and efficient. So translation teaching should also keep abreast with the times and include this technology (Internet Aided Translation) in its curriculum. As Mr. Chen Pei, a search-engine specialist, said, "Besides IQ and EQ, what do you think is the key factor for people's success in the information overloaded 21st century? It is SQ (search quotient) — human ability to obtain knowledge through search engines. [6]” From his saying, it is clear that the concept of SQ is not accidental but inevitable in the development of information technology. With the help of Internet people's lives become easy in all aspects, including translation. The Internet can be considered as a databank of massive information which can be used by translators as huge dictionaries in the work of translation. Translators are required to have bilingual and technique competence. And to use the Internet well is the technique competence that translators should have and translation teaching should consist of. The following tells how the Internet can be used to help translators and gives enlightenment on Internet aided translation teaching.

\section{A. Resource sharing: the online encyclopedia and dictionaries}

Translation is a difficult activity that requires the translators to have industry knowledge in all fields. But it is impossible for translators to have industry knowledge in all fields, so translators need to consult large amounts of references. The Internet provides with the translators a variety of resources, like encyclopedias, dictionaries and professional resources. Wikipedia is the most popular free web encyclopedia which has editions in 253 languages. Online dictionaries make translators easy to consult dictionaries in all languages and all professions in seconds and greatly improve the translating efficiency.

\section{B. The search engine: Google}

Google is a large open Internet space which offers web search, e-mails, online translation, map and pictures, etc. It takes only seconds to find the translation for the terms typed into. There are many ways to use Google to help the translators.

Temptation, a way of searching by tempting the target. For instance, if the English translation of "Automatische Übertragung (German)" is to be found, then type (“Automatische Übertragung”+“automatic”) into Google, for the translator is sure that "automatic" must be the translation of the German word "Automatische". When both of "Automatische" and "automatic" are typed as the search terms, it turns to be more possible for the search engine Google to find the bilingual terms thus get the needed translation.

Proofreading, a way of checking the translation. For instance, if the translator wants to know whether "a flock of sheep" or "a sheep herd” is correct. He can type both "a flock of sheep" and "a sheep herd" into Google and see the searching result number. By doing so, it is found that there exists 279, 000 "a flock of sheep" and only 5,800 “a sheep herd". So the higher search result shows the right lexical collocation is "a flock of sheep".

Google image, a way of searching the image of the object to be translated. For instance, if the translator is not sure what "angle batten holder" is and fails to get the meaning by checking the dictionary, the translator can click http:// images. google.com/ to search the image of "angle batten holder" as the following fig.1 shows.

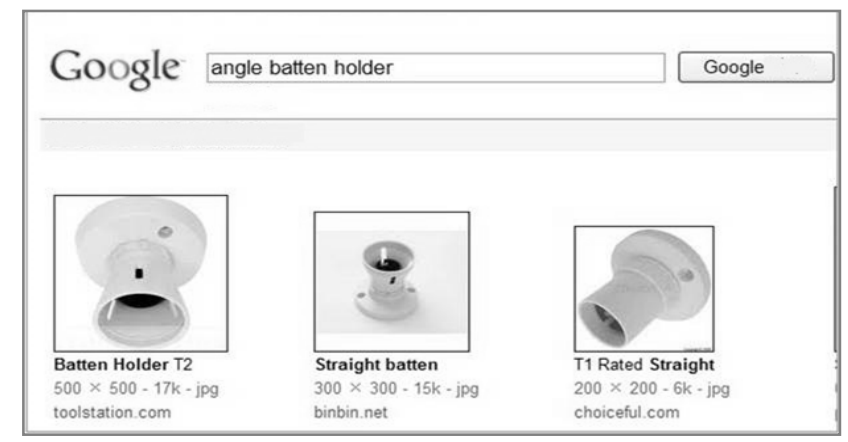

Fig. 1. Example of Google image.

By searching the image, the translator gets to know what "angle batten holder" is with the vivid picture in mind. Since there exists no such a term in dictionary, the translator can create a term in the target language. The above examples tell how the Internet helps translators and it is of great significance to have technology of Internet aided translation in translation teaching for English majors.

\section{CONCLUSION}

Translation course is a practical course. While translation teaching is also a difficult and complex work. In translation teaching, the teachers must adhere to translation theory, focus on translation practice to cultivate qualified and proficient translation talents. At the same time, it is found that the research of translation teaching has not made any achievement and awaits the translation teachers and experts to engage themselves in translation teaching research and together to seek more appropriate ways for translation teaching.

\section{REFERENCES}

[1] Wang Zhanbin, "Investigation and Research on Translation Teaching for English Majors," Shanghai Journal of Translators, vol.1, 2005, pp. 23-25.

[2] Chen Jing, "Flipped Classroom Teaching Model Research,” Journal of Jiamusi Vocational Institute, vol 12, 2015, pp.355.

[3] Liu Jichun, "On the Translation of Foreign Trade Letters," Modern Foreign Language, vol 4, 1996, pp. 54.

[4] Eugene Nida, Charles Taber. "The Theories and Practice of Translation," Shanghai Foreign Language Education Press, 2004.

[5] Li Yunxing, “On Discourse Translation Teaching," Journal of Chinese Translators, vol 4, 2003, pp. 23-25.

[6] Pei Chen. "Search Quotient: the 3rd human capacity," Tsinghua University Press, 2006. 